Technical Reports

\title{
Fatty Acid Composition of Rapeseed Oils of Japanese Old Type Varieties
}

\author{
Megumi YAMAZAKI ${ }^{*}$ and Akihiko NAGAO* \\ * National Food Research Institute, Ministry of Agriculture, Forestry \\ and Fisheries, 2-1-2 Kannondai, Tsukuba, Ibaraki 305
}

\begin{abstract}
Rapeseed oils from Japanese old type rapeseed varieties are rich in erucic acid. Rapeseed oil with high erucic acid content is said to be harmful in nutrition. Therefore, rapeseeds with low content or whithout erucid acid have been developed in Japan and many countries of the world. The fatty acid composition of rapeseeds of Japanese old type varieties was examined. Main fatty acid composition of Towada rapeseeds grown in Aomori prefecture in 1982 was as follows : Oleic acid, 16\%; linoleic acid, 13\%; linolenic acid, $8 \%$; icosenoic acid, $10 \%$ and erucic acid, $45 \%$. The fatty acid composition of the same rapeseeds in the same area in 1983 was similar to that in the previous year. The fatty acid composition of Oomi rapeseeds grown in Kagoshima prefecture in 1982 was similar to that in Aomori prefecture in same year. Of the twelve old type varieties of rapeseeds which were grown in Iwate prefecture, eleven contained erucic acid in seeds oils at levels ranging from 42 to $49 \%$ and oleic acid from 11 to $17 \%$. There was a negative correlation between percentages of erucic and oleic acids. There was a linear relationship $(r=0.795)(1)$ between oleic $(Y)$ and erucic $(X)$ acids percentage, except for 'Aomori-1'.
\end{abstract}

$$
Y=(-0.7246 X)+47.24
$$

There was also a linear relationship $(r=0.847)$ (2) between percentages of oleic $(Y)$ and erucic $(X)$ acids in all rapeseeds analyzed and reported data.

$$
Y=(-0.4348 X)+34.25
$$

Rapeseed oil has been used for a long time in Japan. According to reference materials, it became to be used as edible and lamplight oils in "Minreki era" (about 1655-1657 A.D.). The amount of production of rapeseed in Japan varied with demand in each period. After World War II, it increased rapidly by the encouragement of Japanese government for a self supporting plan of fat and oil resources and crops for cash income. In 1975, it attained the highest record of 109800 tons and its oil accounted for $33 \%$ of the domestic fats and oils.

Afterwards, the production of rapeseed decreased due to its low productivity. At present rapeseed is cultivated in a small scale in the limited regions.

Generally, rapeseed varieties in Japan are classified roughly into two species, Brassica napus $L$. and Brassica campestris L. Most of the old type varieties belong to the former and their grains are dark brown or black and comparatively large. The yield of the former is higher than the latter. The characteristic of the former oil contains high amount of erucic acid (22:1 n-9). Erucic acid is not detectable in most of edible fats and oils, but it is found in some oils (for example, turnip oil, mustard oil and cabbage oil, etc.) besides rapeseed oil.

In 1950's, animal experiments with rapeseed oil added to feed showed inferior growth ${ }^{1 \text {, }}$, high cholesterol level in kidney ${ }^{2)}$ and myocardinal necrosis ${ }^{3)}$ in heart. These defects in the nutrition of rapeseed oil were concluded to be derived from erucic acid, a characteristic con- 
stituent of rapeseed oil.

Canada, where a large amount of rapeseed is produced has promptly developed the production of rapeseed oil with low erucic acid content. It was clarified that erucic acid content in rapeseed is regulated by two genes ${ }^{4}$. In 1963, non erucic acid rapeseed variety, which contains almost no erucic acid, was developed ${ }^{4)}$. Then breeding of rapeseed was carried out in many countries, and new varieties have been created mainly in Europe. In Japan, research on rapeseed breeding is still in progress ${ }^{5}$.

A loss of body weight of rat fed with rapeseed oil was pointed out to be attributed to low absorption of erucic acid ${ }^{2}$. However, it is said to be the case with rat, but not with human ${ }^{6}$.

We think that high erucic acid rapeseeds in Japan will vanish into thin air under such situation sooner or later, and it is yet to be worked out whether high erucic acid rapeseed oil has a harmful effect of human health or not. There are few reports on fatty acid compositions of rapeseeds of Japanese old type varietieds. We compared the fatty acid composition of rapeseeds grown in northern region with those in southern region, namely, Towada grown in Aomori prefecture and Oomi grown in Kagoshima prefecture. We also examined annual variation in fatty acid composition of rapeseeds, Towada grown in Aomori, and also fatty acid composition of twelve rapeseed varieties cultivated in Iwate prefecture. Then, fatty acid composition of Japanese old type varieties was compared with those (reported data) of world old type varieties.

\section{Materials and Methods}

\section{Materials}

Ten samples (five in Hachinohe, three in Kamikita-gun Yokohama, one in Towada and one in Kanaki) in 1982 and eight samples (six in Hachinohe, one in Towada and one in Kanaki) in 1983, Towada varieties in Aomori, were supplied from Aomori Local Food Agency Office. Meanwhile twenty samples (eight in Kaya, six in Ibusuki-gun. Ei, three in Soo-gun and three in Imizu) in 1983, Oomi varieties in
Kagoshima, were sent from Kagoshima Local Food Agency Office. Twelve Japanese old type varieties grown in Iwate, that is, 'Aburamasari', 'Aomori-1', 'Asahi', 'Oomi', 'Chikuzen', 'Chisaya', 'Haya', 'Michinoku', 'Murasaki', 'Norin-14', 'Tairyu' and 'Tsukushi' were supplied from Northeast Agricultural Experiment Station, Ministry of Agriculture, Forestry and Fisheries.

Fatty acid analysis

Rapeseed oil was extracted three times with a mixture of chloroform and methanol $(2: 1$, $\mathrm{v} / \mathrm{v})$ from rapeseeds. Each extract was combined and rapeseed oil was obtained by solvent evaporation.

Fatty acid methylesters of rapeseed oil were prepared as follows. One gram of oil and $50 \mathrm{~m} l$ sulfuric acid-benzene-methanol solution (a mixture of $2 \mathrm{ml}$ concentrated sulfuric acid and $230 \mathrm{~m} l$ mixture of benzene and methanol $(3: 1, \mathrm{v} / \mathrm{v}))$ was added into a reaction flask and then refluxed with a hot water bath for $2.5 \mathrm{~h}$. After the reaction was terminated, the reaction mixture was transferred into a separate funnel. After adding $100 \mathrm{~m} l$ of water into the funnel, fatty acid methylesters were extracted twice with $50 \mathrm{~m} l$ of petroleum ether. Extracts were combined, then washed with water until it becomes neutral. The washed extract was directly subjected to a gas-liquid chromatographic (GLC) analysis, which was carried out with a Shimadzu GC-7 AG instrument equipped with a flame ionization detector (Shimadzu Co., Kyoto, Japan). 20\% DEGS (Diethylene glycol succinate) with a Uniport KAW $60 \sim 80$ mesh $(2.6 \mathrm{~mm} \times 2.1 \mathrm{~m})$ asa column. The carrier gas was $\mathrm{N}_{2}$ at a flow rate of $50 \mathrm{ml} / \mathrm{min}$. And a capillary column (a G-SCOT column, $40 \mathrm{~m} \times 0.28 \mathrm{~mm}$, coated with Silar 5 CP, Gasukuro Kogyo Co., Tokyo, Japan) was also used. The carrier gas was $\mathrm{N}_{2}$ at a flow rate of $0.95 \mathrm{ml} / \mathrm{min}$ and a split ratio of $1 / 58$. Both columns were operated isothermally at $190^{\circ} \mathrm{C}$; injector and detector temperature were $230^{\circ} \mathrm{C}$.

\section{Results and Discussion}

Annual variation of fatty acid composi- 
tion of Towada in Aomori

Fatty acid composition of Towada in 1982 and 1983 is shown in Table 1 (1), (2).

Rapeseed oils of Towada consisted of ca. 45 $\%$ erucic, $14 \sim 16 \%$ oleic, $13 \sim 14 \%$ linoleic, $10 \%$ icosenoic and $8 \%$ linolenic acids. Though some small annual variation was seen concerning the percentages of oleic and linoleic acids, the whole fatty acid composition of Towada in 1982 and 1983 was very similar. No significant differences in the main fatty acids were found except for linoleic acid.

It is known that fatty acid compositions of many plant seeds such as sunflower ${ }^{7) 8 \text { ) }}$ and soybean ${ }^{9)}$ are influenced by temperature during maturation period.

CANVIN ${ }^{10)}$ reported that erucic acid percentage was about $40 \%$ at $16^{\circ} \mathrm{C}$ and about $23 \%$ at $26^{\circ} \mathrm{C}$ when rapeseed was grown under the controlled environmental temperature. From the

Table 1 Fatty acid composition of rapeseed oils grown in Aomori

\begin{tabular}{cllllllc}
\hline \hline Species & & $14: 0$ & $16: 0$ & $16: 1$ & $17: 1$ & $18: 0$ & $18: 1$ \\
\hline (1) Towada (n=10) & Min. & 0.03 & 2.57 & 0.22 & 0.06 & 0.88 & 15.00 \\
in Aomori (1982) & Max. & 0.05 & 2.90 & 0.25 & 0.08 & 1.06 & 16.76 \\
& Mean & 0.04 & 2.77 & 0.23 & 0.07 & 0.96 & 15.64 \\
& S.D. & 0.006 & 0.100 & 0.010 & 0.006 & 0.047 & 0.609 \\
(2) Towada (n=8) & Min. & 0.03 & 2.89 & 0.26 & 0.04 & 0.85 & 12.48 \\
in Aomori (1983) & Max. & 0.12 & 3.51 & 0.34 & 0.06 & 1.07 & 18.04 \\
& Mean & 0.07 & 3.20 & 0.31 & 0.05 & 0.95 & 14.88 \\
& S.D. & 0.035 & 0.244 & 0.029 & 0.007 & 0.074 & 1.816 \\
(3) Oomi (n=20) & Min. & 0.03 & 2.73 & 0.22 & 0.04 & 1.03 & 11.10 \\
in Kagoshima (1982) & Max. & 0.09 & 3.57 & 0.39 & 0.12 & 1.28 & 16.82 \\
& Mean & 0.05 & 3.13 & 0.26 & 0.07 & 1.12 & 14.00 \\
& S.D. & 0.016 & 0.236 & 0.041 & 0.018 & 0.077 & 1.322 \\
\hline
\end{tabular}

Table 2 Fatty acid composition of

\begin{tabular}{llllllll}
\hline \hline \multicolumn{1}{c}{ Variety } & $14: 0$ & $16: 0$ & $16: 1$ & $17: 1$ & $18: 0$ & $18: 1$ & $18: 2$ \\
\hline Aburamasari & 0.04 & 2.70 & 0.25 & 0.05 & 0.89 & 17.20 & 11.61 \\
Aomori-1 & 0.05 & 3.47 & 0.28 & 0.07 & 0.84 & 17.34 & 18.66 \\
Asahi & 0.04 & 3.31 & 0.34 & 0.06 & 1.00 & 16.53 & 14.29 \\
Chikuzen & 0.05 & 3.45 & 0.31 & 0.06 & 1.11 & 16.95 & 13.57 \\
Chisaya & 0.04 & 3.09 & 0.30 & 0.04 & 0.93 & 13.19 & 13.63 \\
Haya & 0.05 & 3.68 & 0.36 & 0.06 & 1.05 & 13.45 & 12.80 \\
Michinoku & 0.05 & 3.42 & 0.34 & 0.06 & 0.90 & 13.64 & 12.74 \\
Murasaki & 0.04 & 3.24 & 0.28 & 0.05 & 0.78 & 12.87 & 12.31 \\
Norin-14 & 0.05 & 3.60 & 0.31 & 0.04 & 0.93 & 12.61 & 13.53 \\
Oomi & 0.04 & 3.54 & 0.30 & 0.05 & 0.87 & 11.39 & 14.23 \\
Tairyu & 0.04 & 3.18 & 0.24 & 0.07 & 0.84 & 15.57 & 12.80 \\
Tsukushi & 0.04 & 3.02 & 0.29 & 0.04 & 0.83 & 16.05 & 13.64 \\
Min. & 0.04 & 2.70 & 0.24 & 0.04 & 0.78 & 11.39 & 11.61 \\
Max. & 0.05 & 3.68 & 0.36 & 0.07 & 1.11 & 17.34 & 18.66 \\
Mean & 0.044 & 3.31 & 0.30 & 0.05 & 0.91 & 14.73 & 13.65 \\
S.D. & 0.005 & 0.279 & 0.036 & 0.011 & 0.097 & 2.085 & 1.761 \\
\hline & & & & & & &
\end{tabular}


above fact finding that there were no significant difference in main fatty acid among the years, the temperature during maturation period might be similar.

Fatty acid compositions of Oomi in Kagoshima

Fatty acid composition of twenty samples of Oomi in Kagoshima in 1982 is shown in Table 1 (3). Composition of main fatty acids, was 45 $\%$ erucic, $14 \%$ oleic, $14 \%$ linoleic, $10 \%$ icosenoic and $9 \%$ linolenic acids. They were compared with those of Towada in Aomori harvested in the same year. Large differences in the fatty acid composition among them were naturally expected, because temperature during maturation was different between Aomori and Kagoshima. However, oleic acid in Oomi was only $2 \%$ lower, linoleic and linolenic acids were $1 \%$ higher. The difference between both fatty acid compositions was not significant. Then,

Prefecture $(1982,1983)$ and Kagoshima Prefecture (1982)

\begin{tabular}{cllcllllll}
\hline \hline $18: 2$ & $18: 3$ & $20: 0$ & $20: 1$ & $20: 2$ & $22: 0$ & $22: 1$ & $22: 2$ & $24: 0$ & $24: 1$ \\
\hline 11.30 & 7.72 & 0.66 & 9.30 & 0.53 & 0.60 & 44.24 & 0.63 & 0.25 & 0.92 \\
13.46 & 8.49 & 0.84 & 10.62 & 0.80 & 0.84 & 46.97 & 0.79 & 0.41 & 127 \\
12.71 & 8.17 & 0.75 & 9.82 & 0.64 & 0.67 & 45.42 & 0.70 & 0.32 & 1.08 \\
0.692 & 0.318 & 0.054 & 0.438 & 0.074 & 0.070 & 0.840 & 0.060 & 0.052 & 0.133 \\
12.93 & 7.84 & 0.58 & 8.54 & 0.52 & 0.40 & 43.66 & 0.43 & 0.18 & 1.00 \\
15.25 & 9.34 & 0.76 & 10.42 & 0.81 & 0.59 & 46.66 & 1.14 & 0.48 & 1.27 \\
14.02 & 8.49 & 0.67 & 9.51 & 0.65 & 0.53 & 44.60 & 0.66 & 0.25 & 1.15 \\
0.870 & 0.518 & 0.052 & 0.618 & 0.117 & 0.067 & 1.105 & 0.261 & 0.095 & 0.102 \\
11.81 & 7.38 & 0.75 & 8.29 & 0.55 & 0.58 & 42.26 & 0.56 & 0.17 & 0.90 \\
14.76 & 9.65 & 1.13 & 11.62 & 1.35 & 1.11 & 46.82 & 1.04 & 0.46 & 1.24 \\
13.48 & 8.48 & 0.90 & 9.95 & 0.82 & 0.78 & 44.91 & 0.78 & 0.26 & 1.05 \\
0.851 & 0.562 & 0.088 & 0.872 & 0.216 & 0.145 & 1.155 & 0.136 & 0.070 & 0.107 \\
\hline
\end{tabular}

rapeseed oils grown in Iwate Prefecture

\begin{tabular}{ccccccccc}
\hline \hline $18: 3$ & $20: 0$ & $20: 1$ & $20: 2$ & $22: 0$ & $22: 1$ & $22: 2$ & $24: 0$ & $24: 1$ \\
\hline 10.32 & 0.57 & 9.08 & 0.39 & 0.40 & 44.77 & 0.46 & 0.08 & 1.19 \\
10.12 & 0.14 & 11.70 & 0.82 & 0.24 & 34.53 & 0.58 & 0.18 & 0.99 \\
8.95 & 0.61 & 8.50 & 0.57 & 0.45 & 43.47 & 0.53 & 0.26 & 1.08 \\
9.16 & 0.66 & 10.09 & 0.48 & 0.38 & 42.25 & 0.50 & 0.11 & 0.87 \\
11.69 & 0.89 & 8.22 & 0.82 & 0.76 & 44.08 & 0.91 & 0.32 & 1.09 \\
10.56 & 0.75 & 7.77 & 0.41 & 0.77 & 46.25 & 0.65 & 0.29 & 1.10 \\
10.12 & 0.63 & 7.63 & 0.51 & 0.67 & 47.24 & 0.69 & 0.21 & 1.12 \\
10.77 & 0.62 & 7.36 & 0.47 & 0.65 & 48.42 & 0.73 & 0.14 & 1.23 \\
10.62 & 0.72 & 8.34 & 0.57 & 0.50 & 46.15 & 0.78 & 0.26 & 0.92 \\
10.56 & 0.64 & 6.86 & 0.55 & 0.63 & 48.09 & 0.86 & 0.22 & 1.15 \\
10.74 & 0.51 & 8.61 & 0.54 & 0.50 & 44.35 & 0.51 & 0.27 & 1.21 \\
10.41 & 0.68 & 10.00 & 0.66 & 0.48 & 42.10 & 0.43 & 0.21 & 1.09 \\
8.95 & 0.14 & 6.86 & 0.39 & 0.24 & 34.53 & 0.43 & 0.08 & 0.87 \\
11.69 & 0.89 & 11.70 & 0.82 & 0.77 & 48.42 & 0.91 & 0.32 & 1.23 \\
10.31 & 0.618 & 8.68 & 0.57 & 0.54 & 44.34 & 0.64 & 0.21 & 1.09 \\
0.725 & 0.178 & 1.361 & 0.139 & 0.162 & 3.725 & 0.160 & 0.074 & 0.111 \\
\hline
\end{tabular}


the maturation periods and their average temperature in both fields in 1982 were studied. Towada in Aomori flowered in the middle of May and was harvested on $10 \sim 15$ th of July. The average temperature during three months (May, June and July) of this year in Aomori was $17^{\circ} \mathrm{C}$. On the other hand, Oomi in Kagoshima flowered on March 10 and was harvested on May 20. The average temperature during three months (March, April and May) of this year in Kagoshima was $16.8^{\circ} \mathrm{C}$. The average temperature during three months of maturation was nearly the same.

If there was no significant difference in fatty acid compositions between two varieties, similar fatty acids composition might be attributed to the similar temperature of ripenning period.

Fatty acid composition of twelve rapeseed oils of Japanese old type varieties

Fatty acid composition of twelve rapeseed oils of Japanese old type varieties cultivated in Iwate is shown in Table 2.

Fatty acid composition of 'Aomori-1' in Table 2 was considerably different from those of Table 1 (1), (2) and (3). Erucic acid percentage of 'Aomori-1' was $34.5 \%$ and it was about $10 \%$ lower than the other varieties. On the other hand, linoleic (18.7\%) was $4 \sim 7 \%$ higher. Table 3 shows data of fatty acid composition of two Brassica napus by MATtson and VolPENHEIN ${ }^{11)}$, one Swedish rapeseed, one Canadian rapeseed and one Brown sarson by TREMAzi et al. ${ }^{12)}$ and one Brassica napus by SzCZEPANSKA ${ }^{13)}$. Main fatty acids of these rapeseeds are the same as those of Japanese old type varieties, such as erucic, oleic, linoleic, linolenic and icosenoic acid. Accordingly, the fatty acid pattern between the former and the latter is similar. However, when comparison between the two was done on an individual fatty acid, there were some differences. For example, though oleic acid percentage in Japanese old type varieties is $11.39 \sim 17.34 \%$, $22 \%$ and $20.9 \%$ in No.1 and No. 2 of Table 3 , while $9.6 \%$ in No. 3 . Such differences were found in No. 1 on linolenic acid, in No. 1, No. 4 and No. 5 on icosenoic acid and in No. 3 on erucic acid. When excluding 'Aomori-1', a rapeseed oil with higher oleic acid had a lower percentage of erucic acid and total percentage of both acids was in the range of about $58 \%$ to $61 \%$. This result was consistent with the report of CANVIN ${ }^{10)}$. CRAIG ${ }^{14)}$ and DownEY ${ }^{15}$ ) clarified a negative correlation between oleic and erucic acids in rapeseeds. As compared with erucic acid, 'Aomori-1' indicated an exceptional fatty acid composition among Japanese old type varieties. Then, a relationship between oleic and erucic acids in rapeseed oils of Japanese old type varieties except for 'Aomori-1' was examined and the following equation (1) was obtained.

$$
\begin{aligned}
Y= & (-0.7246 X)+47.24 \quad(1) \quad(\mathrm{R}=0.795) \\
& Y: \text { Oleic acid percentage } \\
& X: \text { Erucic acid percentage }
\end{aligned}
$$

By the way, a relationship between oleic and erucic acids in those including 'Aomori-1' was as follows. The regression line was expressed as $Y=(-0.4042 X)+32.72$, and the correlation coefficient (r) was 0.715 .

A solid line in Fig. 1 shows the relationship between oleic and erucic acids percentages in rapeseed oils of Table 1 and Table 2 .

From Fig. 1, many Japanese old type varie-

\begin{tabular}{|c|c|c|c|c|c|c|c|c|}
\hline Rapeseed & $16: 0$ & $18: 0$ & $18: 1$ & $18: 2$ & $18: 3$ & $20: 1$ & $22: 1$ & \\
\hline (1) Brassica napus & 3 & 2 & 22 & 15 & 14 & 15 & 28 & (J.B.C 236, 189 (1961)) \\
\hline (2) Brassica napus & 4 & 1 & 17 & 17 & 11 & 10 & 40 & $"$ \\
\hline (3) Swedish & 2.7 & 3.6 & 9.6 & 12.4 & 7.3 & 8.0 & 59.4 & (JAOCS, 42, 78 (1965)) \\
\hline (4) Canadian & 1.7 & 0.7 & 20.9 & 14.3 & 8.1 & 13.1 & 41.1 & ( \\
\hline (5) Brown sarson & 0.6 & 0.8 & 12.3 & 13.5 & 11.3 & 13.4 & 48.1 & ( \\
\hline (6) Brassica napus & 4.3 & - & 12.0 & 15.9 & 12.3 & 9.1 & 46.4 & (JAOCS, 43, 151 (1966)) \\
\hline
\end{tabular}
ties are thought to be made by breeding

Table 3 Fatty acid composition of rapeseed oils reported ${ }^{11)-13}$ 


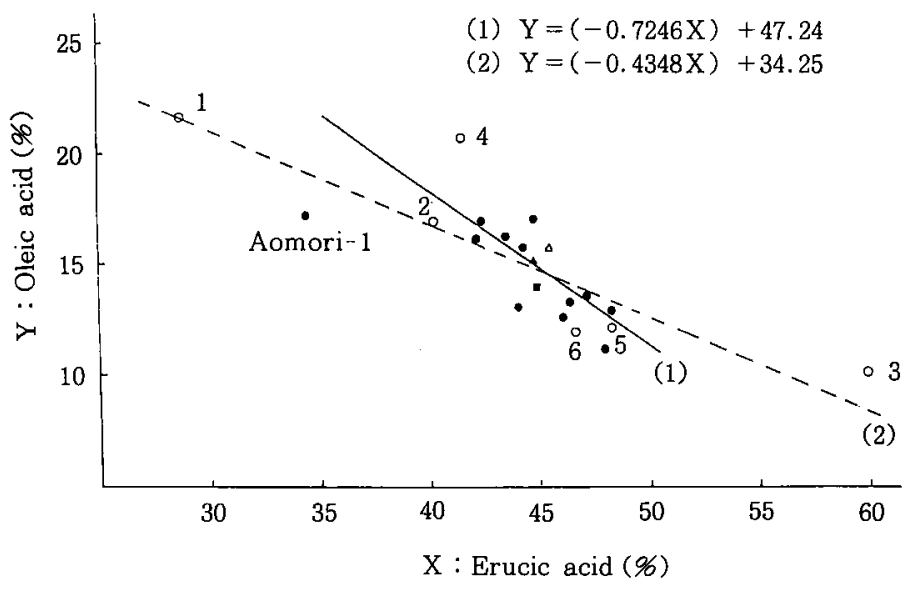

Fig 1. Relationship between oleic acid (Y) and erucic acid (X) in rapeseed oils of Japanese old varieties ( $\mathrm{in}$ Iwate, $\triangle$ in Aomori. 1982, A Aomori. 1983, $\square$ in Kagoshima. 1982) and reported data $(\bigcirc 1-6)$

homologous varieties. But only 'Aomori-1' showed an exceptional case. It is presumed that 'Aomori-1' was either suddenly made by mutation or a gene was introduced from abroad. Then, a relationship between oleic and erucic acids in all rapeseeds in Table 1 , Table 2 and Table 3 was examined and the following equation (2) was obtained.

$$
\begin{aligned}
Y= & (-0.4348 X)+34.25 \\
& Y: \text { Oleic acid percentage } \\
& X: \text { Erucic acid percentage }
\end{aligned}
$$

The relationship between oleic and erucic acid percentages by DowNEY and CRAIG ${ }^{15}$ was closer to Equation (1) than Equation (2).

A broken line in Fig. 1 shows the relationship between oleic and erucic acid percentages in rapeseed oils in Table 1 , Table 2 and Table 3 , which, of course, included 'Aomori-1'. When the relationship between oleic and erucic acids was examined with a broken line which included some rapeseed oils produced in foreign countries, it's presumed that 'Aomori-1' was not exceptional.

\section{References}

1) Thomason, H.J. and Boldingh, J. : $J$.
Nutrition, 56, 469 (1955).

2) Carrol, K.K.: J. Biol. Chem., 200, 287 (1953).

3) Roine, P. Uksila, E. Teir, H. and Rapola, J. : Ernahrungswiss., 1, 118 (1960).

4) Downey, R.K. : Canadian Food Ind., June 1 (1963)

5) Shibata, M. Kaneko, I. Sugawara, S. and Endo, T.: Tohoku Agric. Res., 29, 91 (1981).

6) Vaisey, M. Latta, M. Bruce, V.M. and McDonald, B.E. : Can. Inst. Fd. Sci. Tech. J., 6, 142 (1973).

7) Grindley, D.N. : J. Sci. Food Agric., 3, 82 (1952).

8) NAGAO, A. and YAMAzAKI, M.: Agric. Biol. Chem., 48, 553 (1984).

9) Wolf, R.B. Canvins, J.F. Kleiman, R. and Black, L.T.B.: J. Am. Oil Chem. Soc., 59, 230 (1982).

10) Canvin, D.T.: Can. J. Botany, 43, 63 (1965).

11) Mattson, F.H. and Volpenhein, R.A. : $J$. Biol. Chem., 236, 1891 (1961).

12) Tremazi, S.A. Lovegren, N.V. and Feuge, R.O. : J. Am. Oil Chem. Soc., 42, 78 (1965).

13) Grynberg, H. and Szczepanska, H. : J. Am. Oil Chem. Soc., 43, 151 (1966). 
14) Craig, B.M. : Can. J. Plant Sci., 41, 204 (1961).

15) Downey, R.K. and Craig, B.M. : J. Am. Oil Chem. Soc., 41, 475 (1964).

(Received Oct. 6, 1993)

\section{日本在来種なたね油の脂肪酸組成}

山崎 恵* ・長尾昭彦*

*農林水産省食品総合研究所

（テ305 茨城県つくば市観音台 2-1-2）

在来種なたね油はエルカ酸の多い点を特徽としている.

しかしここのエルカ酸は栄養的に問題であると指摘さ れるに至り，今日，低（零）エルカ酸なたねが多くの国 で誕生している，そこで，消え去る運命の国内在来種な たねの脂肪酸分析を行った。
なたねはひまわり等と同樣にその脂肪酸組成は，登熟 期の温度に影響されるが，同じ年に収權された青森県産 トワダなたねと鹿児島県産オオミなたねの脂肪酸組成は， ほとんど同じといってよかった，調查の結果，青森県産 トワダなたねの登熟期の 5 7 月の 3 ケ月間の平均気温 は $17^{\circ} \mathrm{C}$ ，一方，鹿児島県産オオミなた吅の登熟期の3〜 5 月の 3 ケ月間の平均気温は $16.8^{\circ} \mathrm{C}$ であることが判っ た.

1 品種（アオモリ 1 号）を除き，オレイン酸 $(Y)$ と エルカ酸 $(X)$ の間には, 次の関係(1) が存在した.

$$
Y=(-0.7246 X)+47.24
$$

また，供試全試料及び参考資料データのオレイン酸 $(Y)$ とェルカ酸 $(X)$ の間には，(2)式の関係があった.

$$
Y=(-0.4348 X)+34.25
$$

ちなみに，青森県産トワダなたると鹿児島県産オオミ なたねのエルカ酸は，約 $45 \%$ であった。 